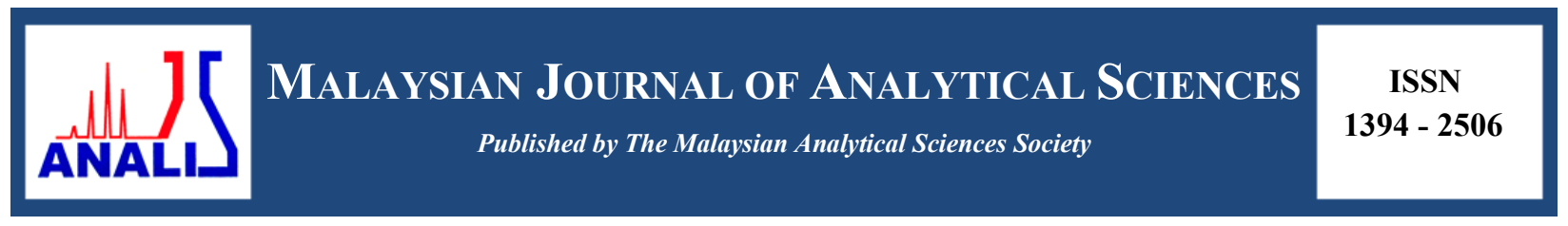

\title{
EFFECT OF MASS LOADING AND MICROWAVE ABSORBER APPLICATION METHOD ON THE PRODUCT FROM MICROWAVE ASSISTED PYROLYSIS OF PALM OIL MILL EFFLUENT
}

\author{
(Kesan Beban Jisim dan Aplikasi Kaedah Penyerap Gelombang Mikro Kepada Produk Terhasil \\ daripada Sisa Buangan Kilang Kelapa Sawit Melalui Proses Pirolisis Bantuan Gelombang \\ Mikro) \\ Zakiuddin Januri ${ }^{1}$, Siti Shawalliah Idris ${ }^{1,2 *}$, Hafifah Amirah Akhawan ${ }^{1}$, Norazah Abd. Rahman ${ }^{1,2,3}$, \\ Sharmeela Matali ${ }^{1,2}$, Shareena Fairuz Abd Manaf ${ }^{1,2}$ \\ ${ }^{I}$ Faculty of Chemical Engineering \\ ${ }^{2}$ CoRe of Green Technology \& Sustainable Development \\ ${ }^{3}$ CoRe of Frontier Materials \& Industry Application \\ Universiti Teknologi MARA, 40450 Shah Alam, Selangor Darul Ehsan, Malaysia \\ *Corresponding author: shawal075@salam.uitm.edu.my
}

Received: 21 October 2015; Accepted: 14 June 2016

\begin{abstract}
Approximately, about 50 million tons of Palm Oil Mill Effluent (POME) is produced every year, however, discharge of POME to open water source will cause negative impact to environment. High production of POME makes it impossible to dispose at the disposal company, therefore, in-situ treatment has been developed. Current disposal method implemented by palm oil industries is through biodegradable pond. This method is applied due to high water content in POME about $90 \%$ of water. Microwave assisted pyrolysis would be an alternative method to deal with the POME since not only can disposed but also can convert to valuable material such as solid char and pyrolytic oil. In this paper, effect of mass loading of POME at a range of 100 to 500 grams with additional activated carbon (AC) was studied. Microwave power level, radiation time and mixing ratio of AC were set constant at $1000 \mathrm{~W}, 30$ minutes and 5\%, respectively. Product yields of solid and liquid were analyzed for the best process performance. Solid char obtained has a potential to be utilized as solid fuel since its energy content was $>20 \mathrm{MJ} / \mathrm{kg}$ and has high carbon content at $>80 \%$. Meanwhile, about $20 \%$ of chemical content in the pyrolytic oil has the carbon number in the range of $\mathrm{C}_{1}$ to $\mathrm{C}_{10}$.
\end{abstract}

Keywords: mass loading, microwave absorber, microwave-assisted pyrolysis, palm oil mill effluent

\begin{abstract}
Abstrak
Dianggarkan lebih kurang 50 juta ton Sisa Buangan Kilang Kelapa Sawit (POME) dihasilkan setiap tahun. Pembuangan POME ke sumber air semulajadi seperti sungai akan menyebabkan impak negatif kepada alam sekitar. Penghasilan POME yang tinggi menyebabkan ianya mustahil untuk dilupuskan oleh syarikat pelupusan, oleh yang demikian, rawatan in-situ dibangunkan. Cara pelupusan terkini oleh industri kelapa sawit adalah melalui kaedah kolam bio-degradasi. Kaedah ini diaplikasikan berikutan kandungan air yang tinggi di dalam POME iaitu lebih kurang 90\% daripada isi kandungannya. Oleh yang demikian, kaedah menambahbaik pirolisis bantuan gelombang mikro (MAP) digunakan dan sekaligus POME dapat dilupuskan dan menukar hasil yang bermanfaat seperti arang pepejal and minyak pirolisis. Di dalam kajian ini, kesan berat kandungan POME di dalam anggaran $100 \mathrm{~g}$ ke $500 \mathrm{~g}$ dengan penambahan karbon aktif diberi tumpuan. Kadar kekuatan gelombang mikro, masa radiasi dan nisbah pencampuran karbon aktif masing - masing dimalarkan pada kadar $1000 \mathrm{~W}, 30$ minit dan 5\%. Penghasilan produk arang pepejal dan minyak pirolitik dianalisis untuk menentukan kadar terbaik penghasilannya. Arang pepejal yang terhasil mempunyai potensi sebagai sumber tenaga dan mempunyai kapasiti tenaga sekurang-kurangnya $>20 \mathrm{MJ} / \mathrm{kg}$ dan mengandungi kandungan
\end{abstract}




\section{Zakiuddin et al: EFFECT OF MASS LOADING AND MICROWAVE ABSORBER APPLICATION METHOD ON THE PRODUCT FROM MICROWAVE ASSISTED PYROLYSIS OF PALM OIL MILL EFFLUENT}

karbon $>8 \%$. Sementara itu, lebih kurang $20 \%$ kandungan bahan kimia di dalam minyak pirolitik terdiri daripada karbon nombor pada kadar $\mathrm{C}_{1}$ to $\mathrm{C}_{10}$.

Kata kunci: beban jisim, penyerap ketuhar gelombang mikro, pirolisis bantuan gelombang mikro, air sisa kilang saw

\section{Introduction}

In general, agriculture is one of the industries that generates large amount of harmful wastes or effluents. Example of effluent produced from agriculture industry is palm oil mill effluent (POME). According to Aziz and Mun, the palm oil industry has generated the highest percentage of effluent as compared to the other agriculture industries [1]. Due to this problem, most of the palm oil mills applied the cheapest alternatives by discharging POME on the land or releasing it into the river. Consequently, this action will cause negative impacts to human health, aquatic life, environment and ecological system such as clogging and water logging of the soil, kills the vegetation on contact, water depletion and aquatic pollution if not treated properly [2]. There are several methods that have been applied in palm oil industry to treat POME such as aerobic, anaerobic, digestion, biodegradation, gasification and ponding treatment [3]. However, there are drawbacks from these methods, which can reduce the efficiency of POME treatment. Lorestani et al., stated that ponding treatment provides longer retention time for the POME to be degraded, low treatment efficiency, large requirement of land, large amount of methane being released and large amount of sludge production [4]. Therefore, there is a potential method as an alternative treatment of POME through microwave pyrolysis. According to Khalid et al. and Salema et al., various studies about microwave heating on POME have been performed by researchers nowadays [5,6]. Microwave pyrolysis can convert POME into three different useful products which are solid-char, liquid and gas. Moreover, microwave pyrolysis provides more advantages compared to the other methods such as shorter exposure time for POME to be degraded and can break down polycyclic aromatic hydrocarbon into low hydrocarbon chain. In addition, microwave pyrolysis is more economical and convenient since it can be operated in-situ [7]. Therefore, the aim for this study is to investigate the feasibility of converting POME into valuable materials such as solid char and pyrolytic oil through microwave assisted pyrolysis process.

About 2.5 tons of palm oil mill effluent (POME) was generated for every ton of palm oil produced. According to Lorestani et al., it was stated that the huge contribution of POME was generated from the combination of wastewater from three main sources which are sterilization, clarification and hydrocyclone processes [4]. POME can be considered as the most harmful waste to human health and environment. POME has high organic load and concentrated colloidal slurry of $95-96 \%$ of water, $0.6-0.7 \%$ of oil and $4-5 \%$ of fine cellulose material [8]. According to Lorestani et al., it was stated that POME contains various suspended materials including short fibers, cell wall, organelles, nitrogenous materials ranging from proteins to amino acids, carbohydrates that ranging from hemicelluloses to a simple sugar, free organic acids and some mineral constituents [4]. Moreover, liquid effluent from palm oil mill includes dissolved constituents such as high concentration of carbohydrates, protein, minerals, nitrogenous compounds and lipids which can be converted into useful materials using specific process. Other than that, POME has a bad odor and thick brownish liquid that contains high solids, oil and grease, high content of chemical oxygen demand (COD) and biochemical oxygen demand (BOD) [2]. It is proven that POME is harmful to human health, aquatic life and environment not only because it contains so much pollutants but the dark brown color itself can impart some negative effect. Therefore, it is necessary to treat the POME before being discharged to the environment.

There are numerous treatments of POME that proposed by several researchers. POME can be treated by conventional method or biological method. However, limited studies on microwave pyrolysis are available particularly relating to treatment of POME. The list of methods and its details are presented in Table 1. As can be seen, the existing methods available had not focused on upgrading the wastes to valuable materials. Thus, microwave assisted pyrolysis technique deems feasible for the recovery of POME to produce valuable materials such as bio-char and pyrolytic oil. 
Table 1. List of palm oil mill effluent treatment methods

\begin{tabular}{lll}
\hline Treatment & Details & References \\
\hline Anaerobic digestion & - Breakdown the biodegradable material without the presence of oxygen & {$[4,8,9]$} \\
& - Produce methane, carbon dioxide and fertilizers & \\
Adsorption by Fungi & - To remove the impurities and colour from the POME. & {$[10]$} \\
& - This treatment takes time as it needs to nurture the fungi. \\
Aerobic biological & - Degradation of organic material with the presence of oxygen. & {$[11,12]$} \\
& - Decrease carbon content and inorganic nitrogen. \\
& - Can change the pH from acidic to alkali. & \\
Facultative pond & - The effluent is discharged to the pond and let it degrades by itself. & {$[13,16]$} \\
& - It takes longer retention time. & {$[14,17]$} \\
\hline
\end{tabular}

Pyrolysis is a heating process of materials without the presence of oxygen. Generally, conventional pyrolysis transfers the heat from outer surface to the center of the material by external heating which includes conduction, convection and radiation [18]. In conventional heating, material is heated volumetrically by heating energy is dissipated through the material from the surface by means of convection, conduction and radiation [19]. In comparison to conventional pyrolysis, microwave pyrolysis technique uses microwave radiation in order to generate heat. As the microwave radiation is penetrated into the material, it causes the electromagnetic energy to be converted into thermal energy. Microwave consists of electric and magnetic field which perpendicular to each other and will cause rotation or collision of the molecules. By referring to the microwave frequency, the molecular dipole inside the material will rapidly rotate about 2450 million times per second and causing frictions that convert the electromagnetic energy into heat [20]. In addition, microwave radiation will penetrate into the material and heat the absorber first [21]. Material that can absorb microwave radiation is called as dielectric [22]. The examples of materials that influence the dielectric properties are water and salt. Therefore, microwave heating is most efficient on the material that contain high amount of dielectric molecules. Since, POME has high moisture content, microwave-assisted pyrolysis is very suitable for treating POME. Additional of microwave absorber material such as activated carbon can enhance microwave assisted pyrolysis process. There are several methods of application of microwave absorber in the microwave assisted pyrolysis process. Microwave absorber could be mixed homogeneously with sample [23] or it can be in separate crucible [21]. Both of these methods could give different effects on the product yields. In this study, both methods were applied in order to study the effect of mass loading toward the method of application of microwave absorber.

\section{Experimental setup}

\section{Materials and Methods}

In this study, the untreated POME was used as a sample for microwave pyrolysis process. The untreated POME sample was collected from the final discharge point in FELDA Serting, Negeri Sembilan before it was channeled to the treatment pond. The samples were prepared in three conditions namely a sample without the presence of activated carbon, a sample mixed homogeneously with activated carbon and a sample with the presence of activated carbon in crucible as stated in Figure 1. Each condition has 5 different mass loading which are 100, 200, 300, 400 and 500g of POME. Activated carbon used in this study was obtained from Sigma-Aldrich. About constant 5\% $\mathrm{wt} / \mathrm{wt}$ of activated carbon was used in this study. Therefore, the mass loadings used in this experiment and the weight percentage of activated carbon used in this study are stated in Table 2. Wet POME sample that had been prepared was placed in a quartz reactor. 


\section{Zakiuddin et al: EFFECT OF MASS LOADING AND MICROWAVE ABSORBER APPLICATION METHOD ON THE PRODUCT FROM MICROWAVE ASSISTED PYROLYSIS OF PALM OIL MILL EFFLUENT}

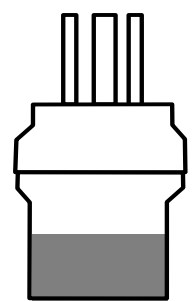

Sample

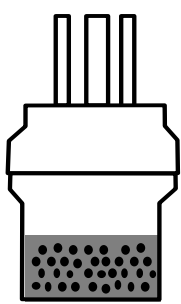

Sample Mixed Homogeneously with Activated

Carbon

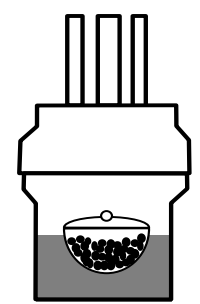

Activated Carbon

Separate in Crucible

Figure 1. Method application of activated carbon in reactor

Table 2. Mass loading and activated carbon ratio

\begin{tabular}{cc}
$\begin{array}{c}\text { Mass of POME Sample } \\
\text { (g) }\end{array}$ & $\begin{array}{c}\text { Weight of Activated Carbon } \\
\text { (g) }\end{array}$ \\
\hline 100 & 5 \\
200 & 10 \\
300 & 15 \\
400 & 20 \\
500 & 25 \\
\hline
\end{tabular}

Then, the reactor was placed into the microwave chamber with a lid having three openings, each for inert gas input, thermocouple and gas exit, respectively. The quartz reactor was purged for duration of 20 minutes with nitrogen gas $(99.9 \%)$ at a flow rate of $250 \mathrm{~mL} / \mathrm{min}$ in order to remove any remaining oxygen. However, the flow rate of nitrogen gas was kept constant at $150 \mathrm{~mL} / \mathrm{min}$ during the process[26]. POME sample was run with the different conditions and mass loadings in order to obtain an optimum mass that can produce highest yields of solid and liquid product. The microwave power input and radiation time were kept constant at $1000 \mathrm{~W}$ and 30 minutes, respectively.

\section{Analytical methods}

The liquid product was condensed in the condenser and collected in the liquid sample holder. After that, the liquid product was washed with hexane and then analyzed with the analytical method. For solid product (char), it is collected once the experiment was completed and analyzed after being cooled down at room temperature. Figure 2 shows the schematic diagram for the microwave pyrolysis system. Solid product which is the solid char obtained was analyzed for its physical properties through proximate, ultimate and calorific analyses was conducted by using thermogravimetric analysis (TGA/ SDTA851) manufactured by Mettler, elemental analyzer (Thermo Finnigan Flashed 1112) and bomb calorimeter (Ika-works C5000 Control Germany D79019), respectively. Meanwhile, pyrolytic oil extracted from the liquid product was analyzed using gas chromatography mass spectrometer (GCMS) model GC Varian 450-GC. Helium was used as a carrier gas at a flow rate of $1 \mathrm{~mL} / \mathrm{min}$. Non-polar capillary column was selected for detection of $\mathrm{C}$ and $\mathrm{H}$ atoms or $\mathrm{C}-\mathrm{C}$ bonds. Oven temperature initially was set at $100{ }^{\circ} \mathrm{C}$ and then it is kept constant for 2 minutes at a heating rate of $5{ }^{\circ} \mathrm{C} / \mathrm{min}$. After that, it was increased to $200{ }^{\circ} \mathrm{C}$ at a heating rate of $10^{\circ} \mathrm{C} / \mathrm{min}$. Then, it was followed by heating to $260^{\circ} \mathrm{C}$ at a heating rate of $4{ }^{\circ} \mathrm{C} / \mathrm{min}$. Temperature was maintained at $260{ }^{\circ} \mathrm{C}$ for 15 minutes. For chromatography, injection temperature was set at $270{ }^{\circ} \mathrm{C}$. Chemical compound in the liquid oil was traced and identified at the setting of mass per ion, $\mathrm{M} / \mathrm{Z}=30-500$. Split ratio was set at 1:10. 


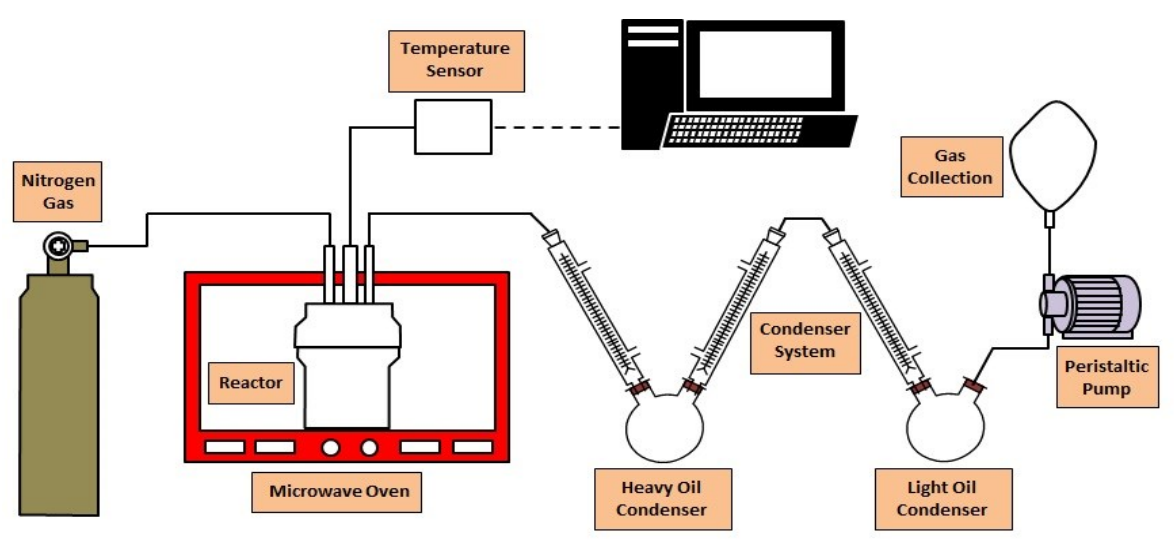

Figure 2. Schematic diagram for microwave pyrolysis system [26]

\section{Raw material characterization}

\section{Results and Discussion}

In general, the characteristic of raw material can be classified into two types which are physical and chemical properties. Physical properties of POME obtained from proximate analysis using Thermogravimetric Analyzer (TGA) Mettler Toledo TGA/SDTA 851 and followed the standard of ASTM D7582-12. Figure 3 shows that water content in dried POME start to vaporize at temperature $40{ }^{\circ} \mathrm{C}$ to $136^{\circ} \mathrm{C}$.

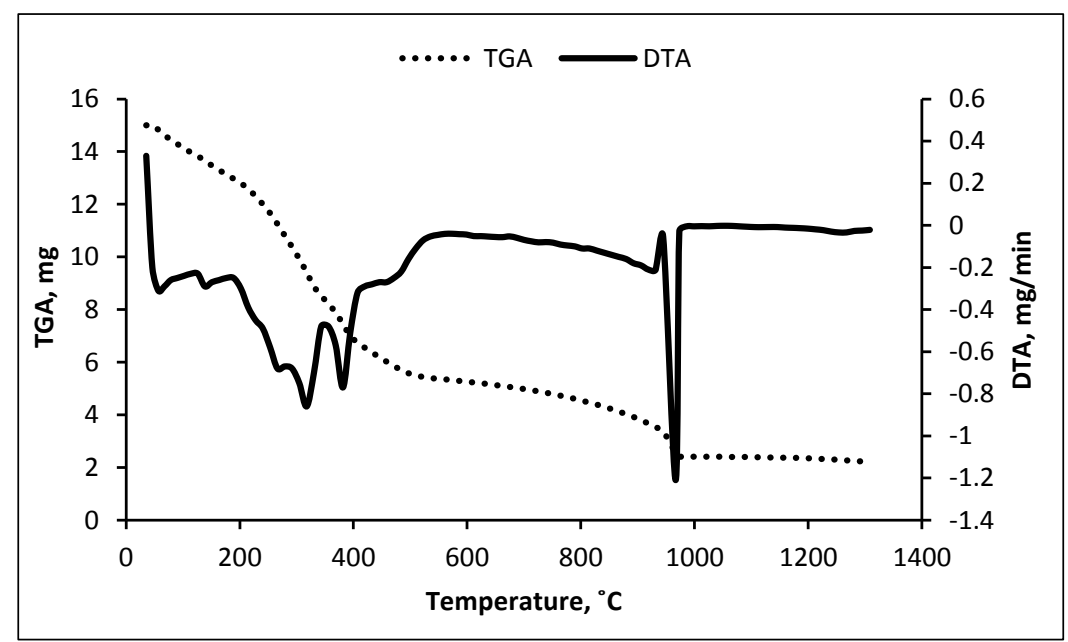

Figure 3. Thermal degradation of proximate analysis of raw material

All volatile matter inside POME starts to degrade at temperature $139{ }^{\circ} \mathrm{C}$ to $939{ }^{\circ} \mathrm{C}$ before it is released to surrounding. The optimum temperature for degradation of POME is known to be at the temperature of $320.13{ }^{\circ} \mathrm{C}$ where all longer hydrocarbons are converted into lower hydrocarbons. Other than that, thermal degradation of proximate analysis of raw material also provides value for moisture content, volatile combustible matter, fixed carbon and ash. Fixed carbon is a combustible residue after volatile matter was removed and ash is a weight of residue after combustion in an open crucible. All the values obtained from proximate analysis are important for raw material characterization. Therefore, the characterization of POME is stated in the Table 3 . Chemical properties of palm oil mill effluent (POME) can be obtained from ultimate analysis, energy content and fusing point of ash. Since 


\section{Zakiuddin et al: EFFECT OF MASS LOADING AND MICROWAVE ABSORBER APPLICATION METHOD ON THE PRODUCT FROM MICROWAVE ASSISTED PYROLYSIS OF PALM OIL MILL EFFLUENT}

POME is in the form of liquid, the physical properties of this raw material can only be analyzed by observation of specific weight such as volume.

Table 3. Characterization of raw palm oil mill effluent (POME)

\begin{tabular}{lc}
\hline Characteristic & $\mathbf{\%}$ \\
\hline Moisture content & 14.4 \\
Volatile combustible matter & 13.7 \\
Fixed carbon & 71 \\
Fixed ash content & 0.9 \\
\hline
\end{tabular}

Ultimate analysis is used to determine the percent of $\mathrm{C}, \mathrm{H}, \mathrm{N}, \mathrm{S}, \mathrm{O}$ and ash. The percent of $\mathrm{C}, \mathrm{H}, \mathrm{N}, \mathrm{S}, \mathrm{O}$ and ash obtained is important in order to identify chemical formula which then can be used in various chemical and biological reactions. However, for this analysis, the chemical composition of POME is obtained from literature. According to Khairuddin et al., the chemical formula for POME is $\mathrm{C}_{25} \mathrm{H}_{5} \mathrm{~N}_{5} \mathrm{SO}_{59}$ [24]. Table 4 shows the percent $\mathrm{C}$, $\mathrm{H}, \mathrm{N}, \mathrm{S}$ and $\mathrm{O}$ of POME obtained from the literature. Energy content is a potentially critical element in combustion. For this study, the energy content of POME is obtained from the literature. In a study by Januri et al., energy content in POME can be considered as high which is $16.16 \mathrm{MJ} / \mathrm{kg}$ [25]. Since the energy content inside POME is high, it has a potential to be used in future as fuel and the source of energy.

Table 4. Ultimate analysis for raw palm oil mill effluent (POME)

\begin{tabular}{lccccc}
\hline Element & $\mathbf{C ~ ( \% )}$ & $\mathbf{H ~ ( \% )}$ & $\mathbf{N}(\mathbf{\%})$ & $\mathbf{S ~ ( \% )}$ & $\mathbf{O ~ ( \% )}$ \\
\hline As Received & 26.57 & 4.97 & 5.66 & 1.05 & 61.78 \\
Dry basis & 31.04 & 3.92 & 6.61 & 1.23 & 56.15 \\
Dry Ash free basis & 31.37 & 5.87 & 6.68 & 1.24 & 54.84 \\
\hline
\end{tabular}

\section{Product yield}

Generally, the pattern of product yield formed from microwave pyrolysis of POME for solid are showed an increment with the increased of mass loadings as shown in Figure 4. However, the conversion of POME into solid char show a divergent pattern as shown in Table 5 as the mass loading increased, the conversion dropped from $\sim 98$ to $\sim 61 \%$. This is due to the condition where water is the dominant inside the POME was activated, self-propagated and vaporized during the pyrolysis but it limited the pyrolysis process condition, which reduced the conversion of solid char. Process of releasing the water content from the POME took place and decreased the pyrolysis reaction. No conversion of solid char was observed for all samples with non-microwave absorber indicating the sample was not fully pyrolyzed even though high conversion was achieved. Meanwhile, sample with microwave absorber regardless it is mixed homogeneously or in separate crucible, solid char was formed at low mass loading below 200 $\mathrm{g}$ with yield and conversion for both mixed homogeneously and in separate crucible were $\sim 1.5 \%$ yields; $\sim 98.5 \%$ conversion and $\sim 3.3 \%$ yields; $96.7 \%$ conversion, respectively. Addition of microwave absorber has increased the reaction temperature and consequently increased the product yields [27]. Solid char was formed with aid of microwave absorber during microwave assisted pyrolysis process. Indeed the introduction of microwave absorber via separate crucible has increased yields of solid char formed. Microwave absorber bed in separate crucible improved the microwave irradiation towards the absorbance properties of POME [21]. Low conversion of solid char was observed at high mass loading at range 300 to $500 \mathrm{~g}$. This was due to the depth of penetration of microwave radiation through the sample. The depth of penetration of microwave energy into the sample is measurement to determine how much the completion of pyrolysis. 


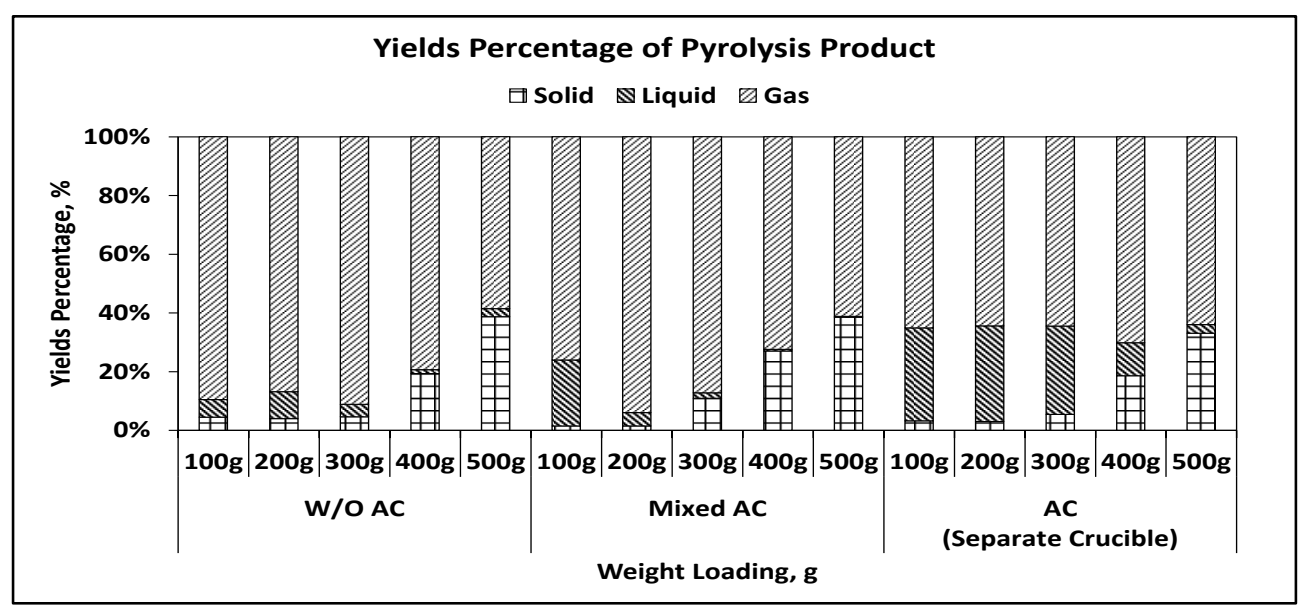

Figure 4. Yield percentage of product distribution

Table 5. Conversion of POME into solid char

\begin{tabular}{lcccl}
\hline Conditions & $\begin{array}{c}\text { Mass Loading } \\
(\mathbf{G})\end{array}$ & $\begin{array}{c}\text { Solid Yields } \\
(\mathbf{\%})\end{array}$ & $\begin{array}{c}\text { Conversion } \\
(\mathbf{\%})\end{array}$ & Visual Result \\
\hline No activated & 100 & 4.50 & 96.00 & Semi coke \\
carbon & 200 & 4.05 & 95.95 & Dried sample \\
& 300 & 4.67 & 95.33 & Dried sample \\
& 400 & 19.40 & 80.60 & Undried sample \\
& 500 & 38.70 & 61.30 & Undried sample \\
\hline With activated & 100 & 1.50 & 98.50 & Char \\
carbon (mix & 200 & 1.50 & 98.50 & Char \\
homogeneously) & 300 & 10.97 & 89.03 & Semi coke \\
& 400 & 27.03 & 72.98 & Undried sample \\
& 500 & 38.54 & 61.46 & Undried sample \\
\hline With activated & 100 & 3.30 & 96.70 & Char \\
carbon (separate & 200 & 3.05 & 96.95 & Char \\
crucible) & 300 & 5.47 & 94.53 & Semi coke \\
& 400 & 18.60 & 81.40 & Dried sample \\
& 500 & 33.08 & 66.92 & Dried sample \\
\hline
\end{tabular}

The practical reason for determining the depth of penetration is to ensure efficient heating of the materials throughout its interior. If the frequencies are higher, the microwave radiation might get absorbed on the surface of the materials, and will penetrate only a short distance [28]. High volume of sample might affect the depth of penetration of microwave radiation. Thus, the presence of activated carbon with high dielectric properties enhanced the depth of penetration of microwave radiation and heated the materials uniformly. It has been stated by R. Meredith (1998), dielectric constant plays an important role in the power penetration [29]. 


\section{Zakiuddin et al: EFFECT OF MASS LOADING AND MICROWAVE ABSORBER APPLICATION METHOD ON THE PRODUCT FROM MICROWAVE ASSISTED PYROLYSIS OF PALM OIL MILL EFFLUENT}

In comparison, yield of liquid product decreased when the mass loading increased as shown in Figure 4. Liquid product yield consists of two components, which are pyrolytic oil and water in the form of aqueous that had been vaporized during the microwave assisted pyrolysis process. This is due to the effectiveness of pyrolysis condition of POME, which is the mass loading to the microwave irradiation. Through observation of Figure 5, yields of liquid product increased with two different methods application of activated carbon as microwave absorber applied. Thus, pyrolytic thermal cracking could be achieved with the application of microwave absorber during microwave assisted pyrolysis process [30]. Consequently it would increase yields of liquid product with the addition of microwave absorber into raw material [27,31]. Activated carbon in separate crucible produced more yields of liquid product and furthermore, the percentage of pyrolytic oil separated from yields of liquid product was also higher compared to pyrolytic oil gain from the process which sample has been mixed homogeneously with activated carbon. It could be said that, microwave assisted pyrolysis process achieved highest reaction temperature from the heating of activated in separate crucible which promoted high hydrocarbon breakdown of POME and produced more pyrolytic oil. Similar trend was observed from other researcher by formed the microwave absorbent bed in the microwave assisted pyrolysis reactor that increased the pyrolytic oil yield [32]. Increase in the mass loading has reduced the pyrolytic oil yields in the yields of liquid product due to the incomplete pyrolysis reached. Hence, sample that has mass loading more than $300 \mathrm{~g}$ in average cannot obtain fully pyrolyzed condition successfully, indicating by the low conversion percentage of solid char, low solid char yields and low pyrolytic oil yields. This can be concluded that $300 \mathrm{~g}$ sample with the presence of microwave absorber can be the maximum mass loading to pyrolyze POME and separated microwave absorbent during microwave assisted pyrolysis process will be the best applicable method for microwave absorbent application in the process.

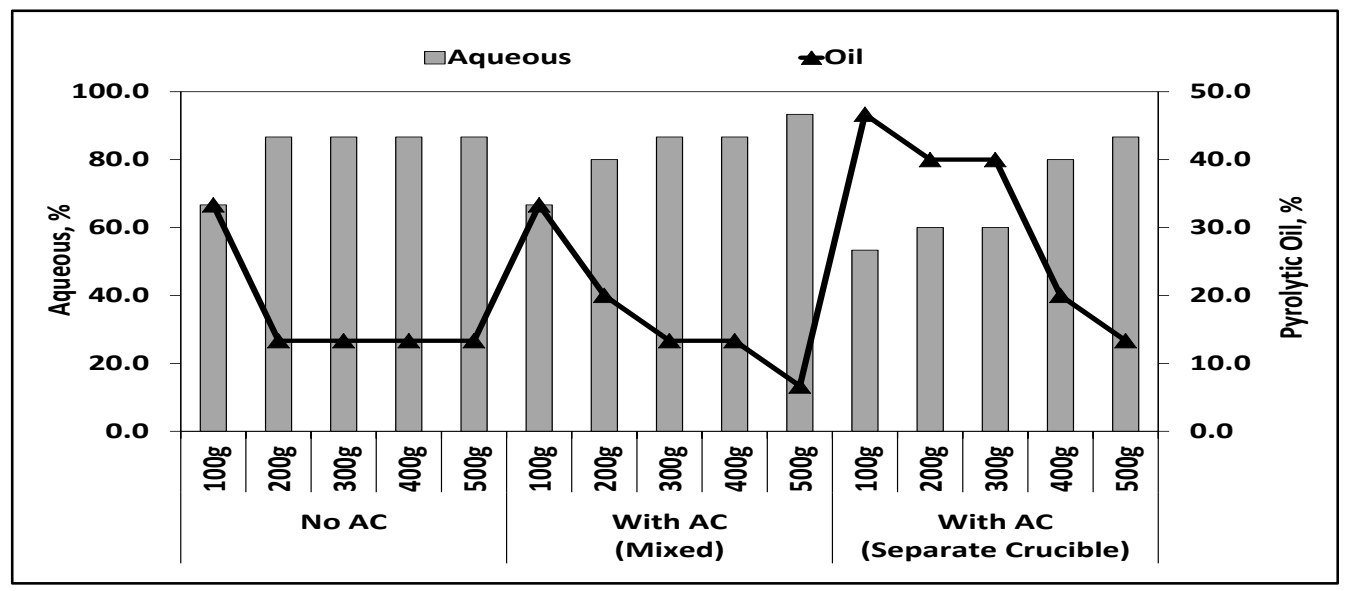

Figure 5. Aqueous -pyrolytic oil percentage extracted from liquid yields

\section{Solid product analysis}

Solid char was analyzed for it physical properties by proximate and ultimate analysis. From the proximate analysis data obtained from Table 6, microwave assisted pyrolysis released the volatile matter out from the raw POME thus it promoted the formation of solid at low mass loading at $100 \mathrm{~g}$. Indeed almost complete pyrolysis was achieved by POME using this method. Lack of dielectric constant properties in raw POME has reduced the potential of microwave assisted pyrolysis.

With the improvised microwave assisted pyrolysis method by the addition of the microwave absorber such as activated carbon, has increased the total dielectric constant of the sample thus enhanced the pyrolysis process through higher temperature [33-35]. It was observed that the addition of microwave absorber (AC), for both mixed homogeneously and in separate crucible has increased the efficiency of pyrolysis through the effectiveness of microwave radiation absorbed and activated more molecule to generate more heat energy at high mass loading such as $200 \mathrm{~g}$ and $300 \mathrm{~g}$ for the method of mixed AC homogeneously and in separate crucible respectively. By releasing 
the higher amount of volatile matter from raw POME during pyrolysis process, it elevated the fixed carbon content in the solid char derived and it is consistent with the findings reported by other researchers on char derived from microwave assisted pyrolysis process [28, 36, 37]. Meanwhile, other research was found on pyrolysis of POME for bio-char, it resulted moisture content and ash content that were consistent with the char obtained [38]. On the other hand, high fixed carbon content in the solid char indicated high percentage of carbon element in the solid char, as can be seen in the ultimate analysis result in Table 6 .

Table 6. Proximate and ultimate analysis of solid product of microwave assisted pyrolysis of POME

\begin{tabular}{|c|c|c|c|c|c|c|c|c|c|c|c|c|}
\hline \multirow{2}{*}{ Conditions } & \multirow{2}{*}{$\begin{array}{c}\text { Sample } \\
\text { (g) }\end{array}$} & \multicolumn{4}{|c|}{ Proximate Analysis } & \multicolumn{7}{|c|}{ *Ultimate Analysis } \\
\hline & & $\% \mathrm{M}$ & $\% \mathrm{VM}$ & $\%$ FC & $\% A$ & $\mathbf{C}$ & $\mathbf{H}$ & $\mathbf{N}$ & $\mathbf{S}$ & $* * \mathbf{O}$ & $\mathrm{H} / \mathrm{C}$ & $\mathrm{O} / \mathrm{C}$ \\
\hline \multirow{5}{*}{$\begin{array}{l}\text { No activated } \\
\text { carbon }\end{array}$} & 100 & 6.46 & 2.93 & 64.2 & 26.41 & 52.05 & 10.22 & 0.00 & 0.00 & 37.73 & 0.20 & 0.91 \\
\hline & 200 & 0.43 & 30.97 & 31.03 & 37.57 & 46.30 & 11.16 & 0.00 & 0.00 & 42.54 & 0.24 & 0.93 \\
\hline & 300 & 2.31 & 40.5 & 35.76 & 21.43 & 48.85 & 9.47 & 0.00 & 0.00 & 41.68 & 0.19 & 0.92 \\
\hline & 400 & 3.94 & 70.64 & 19.95 & 5.47 & 39.96 & 10.85 & 0.00 & 0.00 & 49.20 & 0.27 & 1.34 \\
\hline & 500 & 25.7 & 60.2 & 12.7 & 1.4 & 56.01 & 17.76 & 0.00 & 0.00 & 26.22 & 0.32 & 1.10 \\
\hline \multirow{5}{*}{$\begin{array}{l}\text { With activated } \\
\text { carbon (mix } \\
\text { homogeneously) }\end{array}$} & 100 & 3.1 & 5.21 & 68.89 & 22.8 & 34.66 & 1.90 & 0.00 & 0.00 & 63.44 & 0.05 & 1.95 \\
\hline & 200 & 2.8 & 11.6 & 59.62 & 25.98 & 31.30 & 2.05 & 0.00 & 0.00 & 66.65 & 0.07 & 2.25 \\
\hline & 300 & 7.6 & 21.76 & 33.44 & 37.2 & 42.36 & 4.44 & 0.00 & 0.00 & 53.20 & 0.10 & 1.58 \\
\hline & 400 & 5.2 & 61.8 & 25.06 & 7.94 & 34.29 & 5.28 & 0.00 & 0.00 & 60.43 & 0.15 & 1.94 \\
\hline & 500 & 18.9 & 70.5 & 6.32 & 4.28 & 37.05 & 5.09 & 0.00 & 0.00 & 57.86 & 0.14 & 2.23 \\
\hline \multirow{5}{*}{$\begin{array}{l}\text { With activated } \\
\text { carbon (separate } \\
\text { crucible) }\end{array}$} & 100 & 0.87 & 1.6 & 51.93 & 45.6 & 73.59 & 13.63 & 11.89 & 0.00 & 0.89 & 0.19 & 0.03 \\
\hline & 200 & 1.87 & 8.72 & 52.01 & 37.4 & 81.67 & 6.63 & 7.45 & 0.00 & 4.25 & 0.08 & 0.09 \\
\hline & 300 & 4.6 & 11.6 & 48.7 & 35.1 & 73.52 & 9.66 & 6.14 & 0.00 & 10.68 & 0.13 & 0.25 \\
\hline & 400 & 4.12 & 54.7 & 32.28 & 8.9 & 49.15 & 7.89 & 4.12 & 0.00 & 38.85 & 0.16 & 0.89 \\
\hline & 500 & 12.6 & 49.6 & 30.82 & 6.98 & 40.16 & 9.53 & 2.49 & 0.00 & 47.83 & 0.24 & 1.58 \\
\hline
\end{tabular}

* Dry ash free basis

** Calculated by difference

Elemental content obtained from this analysis is then compared to the coal since coal is used as a solid fuel. According to Jing-biao et al., the percentage of C, H, N, S and O of Baotou bituminous coal are 70.18, 4.64, 1.5, 0.44 and $11.36 \%$, respectively [39]. It was observed that carbon content in the microwave assisted pyrolysis process with the microwave absorber in separate crucible has high carbon content as compared to the one the mixed homogeneously. In comparison to the percentage of $\mathrm{C}, \mathrm{H}, \mathrm{N} \mathrm{S}, \mathrm{O}$ of coal, the solid char obtained from microwave assisted pyrolysis process with microwave absorber in separate crucible had almost identical elemental properties. The $\mathrm{O} / \mathrm{C}$ ratio of the char obtained from microwave assisted pyrolysis process in separate crucible has low value as compared to other process. Solid char obtained has low $\mathrm{H} / \mathrm{C}$ and $\mathrm{O} / \mathrm{C}$ atomic ratio which indicates high carbon content and low hydrogen and oxygen content indicating the presence of low hydrocarbon compound in the solid char. The energy content is determined in order to identify the feasibility of utilizing solid product from pyrolysis of POME as alternative fuel in future. Figure 6 shows the gross calorific value of solid product from microwave pyrolysis of POME. It was observed that gross calorific value for both the chars obtained in the absence and the presence of microwave absorber in the condition of mixed homogeneously were kept increasing at range $100 \mathrm{~g}$ to $300 \mathrm{~g}$ except for the solid char obtained from process that microwave absorber in separate crucible. Its energy content decreased when mass loading increased to $300 \mathrm{~g}$. In addition, sample having mass loading of 400 and $500 \mathrm{~g}$ for all methods/arrangements are known to be zero since the samples were in un-dried condition. Incomplete pyrolysis condition was found in this mass loading. 


\section{Zakiuddin et al: EFFECT OF MASS LOADING AND MICROWAVE ABSORBER APPLICATION METHOD ON THE PRODUCT FROM MICROWAVE ASSISTED PYROLYSIS OF PALM OIL MILL EFFLUENT}

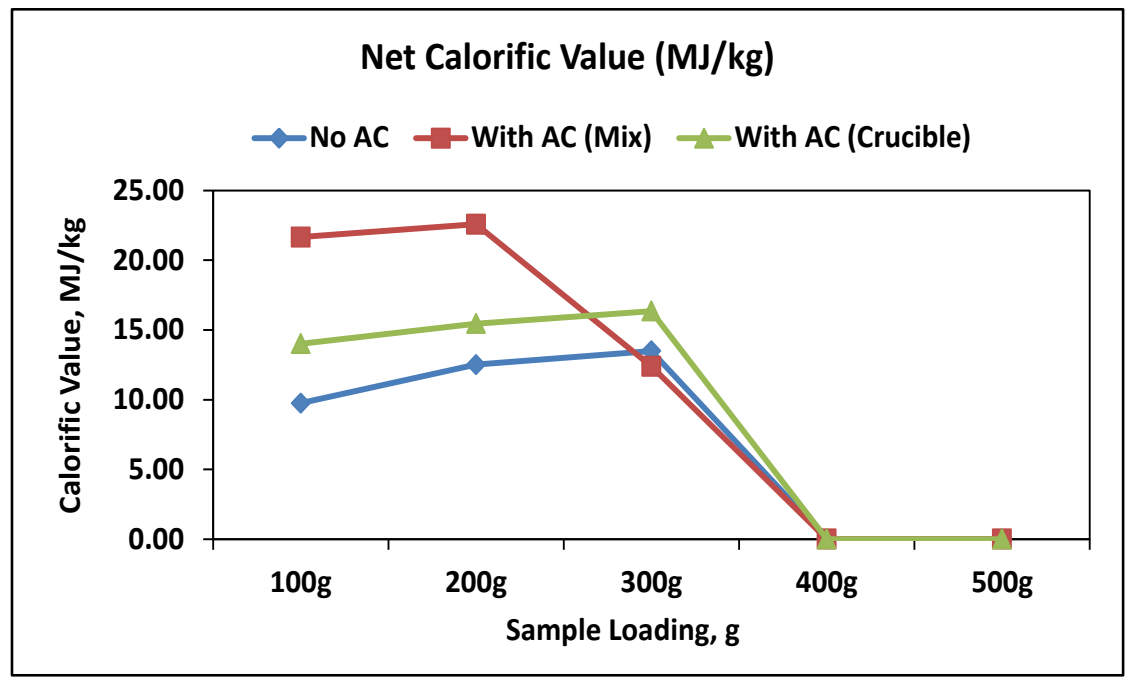

Figure 6. Net calorific value of solid product of POME

It is proven that solid product of microwave pyrolysis of POME that has high energy content which is more than $15000 \mathrm{~J} / \mathrm{g}$ can be used as an alternative fuels in future. According to Thangalazhy-Gopakumar, solid char obtained from pyrolysis of POME was around $12.8 \pm 0.2 \mathrm{MJ} / \mathrm{kg}$ [38]. It is consisted with the energy content obtained from microwave assisted pyrolysis of POME without the presence of microwave absorber. Energy content slightly increased from when it was pyrolysis with the aid of microwave absorber during the microwave pyrolysis process in separate crucible. The presence of microwave absorber increased the reaction temperature and consequently increased the fixed carbon content and elevated the energy content. However, solid char obtained from microwave assisted pyrolysis with the mixed homogeneously with activated carbon has higher energy content from the rest. Activated carbon itself has a quite high of energy content thus it increased the energy content of solid char obtained. Table 7 shows the gross and net calorific value of microwave pyrolysis of POME. The equation used to calculate net calorific value is shown in Equation 1.

Net calorific value, $\mathrm{kJ} / \mathrm{kg}=$ Gross calorific value $-24.44(9 \% \mathrm{H}+\% \mathrm{M})$

\section{Pyrolytic oil analysis}

Pyrolytic oil extracted from liquid product was analyzed for its chemical content by using gas chromatography mass spectrometer (GCMS). Pyrolysis oil extracted from the liquid product contain valuable hydrocarbon that can be potential to recover either in single component or as the oil. Through the observation in Figure 7, it was found that low chain ester such as 1,2-benzenedicarboxylic acid diisooctyl ester, 2-propenoic acid, 2-methyl dodecyl ester, and 9,12-octadecadienoic acid (Z,Z)- phenylmethyl ester was recovered in the pyrolytic oil at low mass loading. It was consistent with research on the pyrolytic oil from sewage sludge by other researchers [40, 41]. Meanwhile the nitrogenated compound was highly observed in the pyrolytic oil from microwave assisted pyrolysis of POME without microwave absorber. Nitrogenated compounds were not favorable for fuels; however, their presence can be reduced by changing the operating parameters [38]. 
Table 7. Gross and net calorific value of solid product of POME

\begin{tabular}{lccc}
\hline Conditions & Sample (g) & $\begin{array}{c}\text { Gross Calorific } \\
\text { Value (MJ/kg) }\end{array}$ & $\begin{array}{c}\text { Net Calorific } \\
\text { Value (MJ/kg) }\end{array}$ \\
\hline No activated carbon & 100 & 11.415 & 9.75 \\
& 200 & 14.042 & 12.51 \\
& 300 & 15.137 & 13.49 \\
& 400 & $\mathrm{n} . \mathrm{d}^{*}$ & $\mathrm{n} . \mathrm{d}^{*}$ \\
& 500 & $\mathrm{n} . \mathrm{d}^{*}$ & $\mathrm{n} . \mathrm{d}^{*}$ \\
\hline With activated carbon & 100 & 22.049 & 21.66 \\
(mix homogeneously) & 200 & 22.965 & 22.58 \\
& 300 & 13.125 & 12.40 \\
& 400 & $\mathrm{n} . \mathrm{d}^{*}$ & $\mathrm{n} . \mathrm{d}^{*}$ \\
& 500 & $\mathrm{n} . \mathrm{d}^{*}$ & $\mathrm{n} . \mathrm{d}^{*}$ \\
\hline With activated carbon & 100 & 15.645 & 14.02 \\
(separate crucible) & 200 & 16.383 & 15.45 \\
& 300 & 17.743 & 16.35 \\
& 400 & $\mathrm{n} . \mathrm{d}^{*}$ & $\mathrm{n} . \mathrm{d}^{*}$ \\
& 500 & $\mathrm{n} . \mathrm{d}^{*}$ & $\mathrm{n} . \mathrm{d}^{*}$ \\
\hline
\end{tabular}

* Not Detected

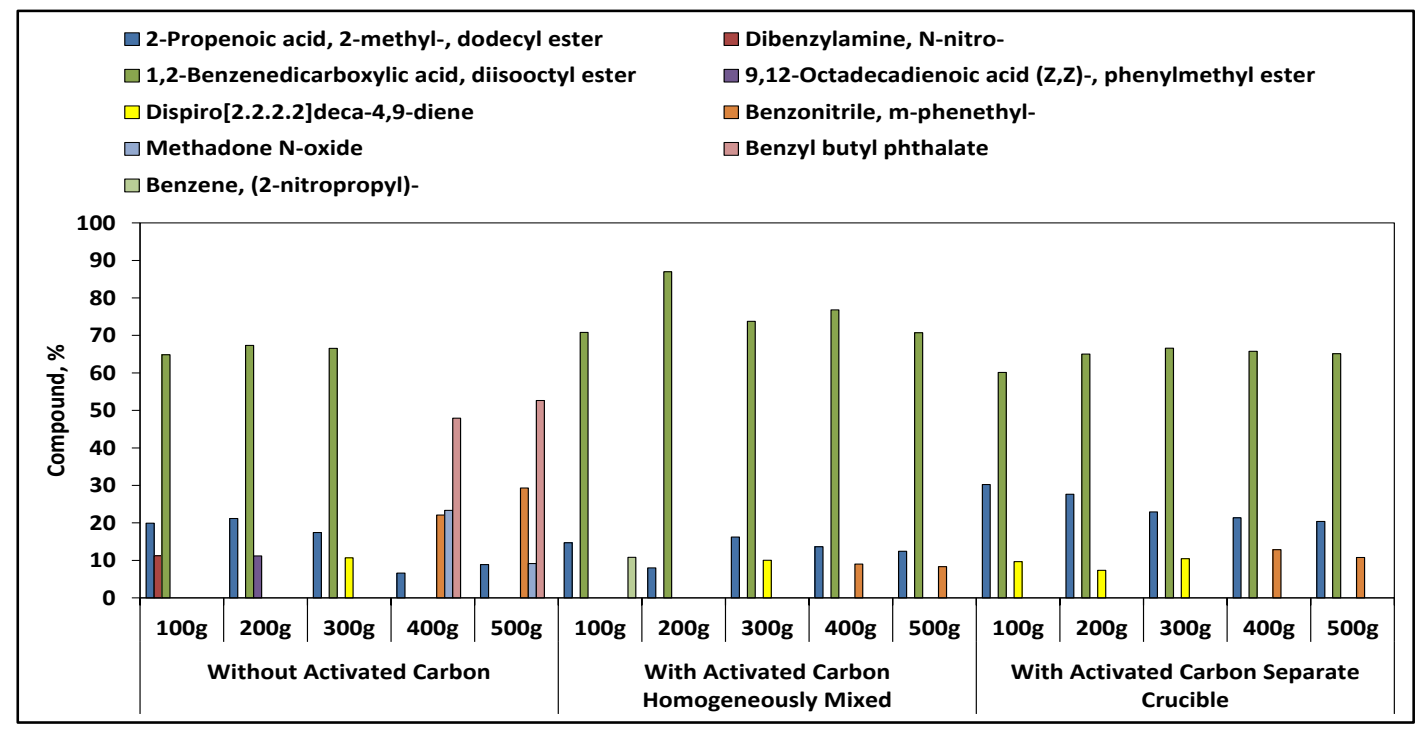

Figure 7. Chemical compound percentage from total ion chromatogram of pyrolytic oil

Thus, pyrolytic oil for both process mixed microwave absorber homogeneously and in separate crucible, eliminated and breakdown the nitrogenated compound into other low hydrocarbon compound. Moreover, low hydrocarbon chain compound production was elevated in the process with microwave absorber in separate crucible as shown in 


\section{Zakiuddin et al: EFFECT OF MASS LOADING AND MICROWAVE ABSORBER APPLICATION METHOD ON THE PRODUCT FROM MICROWAVE ASSISTED PYROLYSIS OF PALM OIL MILL EFFLUENT}

Figure 8. Radiation temperature increased rapidly during the course of pyrolysis when microwave absorber in separate crucible was used. The introduction of microwave absorber added further reaction by increasing the radiation temperature and enhancing the hydrocarbon cracking with the dehydrogenation process through the DielsAlder reaction [42]. With the increased of low hydrocarbon chain in the pyrolytic oil, it would increase the potential of pyrolytic oil to become fuel.

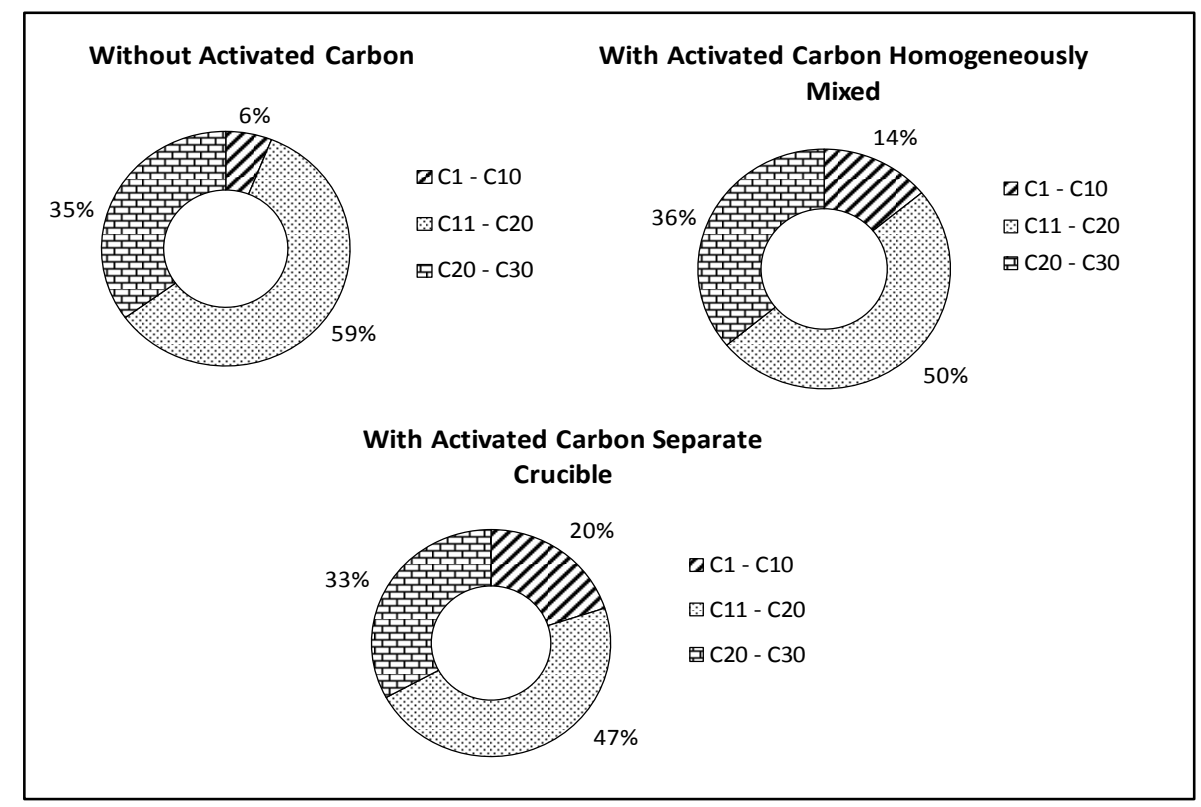

Figure 8. Proportion of chemical compound in pyrolytic oil according to carbon number

\section{Conclusion}

In conclusions, this research has been carried out in order to study the effect of different sample mass loading and method application of activated carbon as microwave absorbent to the product yield of microwave-assisted pyrolysis of palm oil mill effluent (POME). POME cannot be fully pyrolyzed using domestic modified microwave oven with the highest microwave power level and longest radiation time. With the presence of activated carbon either by mixed it homogeneously or in the separate crucible, pyrolysis of POME can be improved. Solid product obtained from this study has high energy and oil extracted from liquid product condensed contain some chemical that has tendency to be an alternative fuel in future. Therefore, microwave-assisted pyrolysis treatment of POME is an alternative way to reduce the waste, hence preventing negative impacts to human and environment such as disease and pollution. These advantages have proven that microwave-assisted pyrolysis technique is able to transform waste into wealth in future.

\section{Acknowledgement}

This work was financially supported by Excellence Research Grant (600-RMI/DANA 5/3/RIF) with the experimental equipment and facility provided by Research Management Institute, Universiti Teknologi MARA (UiTM) and Faculty of Chemical Engineering, UiTM.

\section{References}

1. Aziz, N. A. and Mun, D. L. K. (2012). Malaysia's biomass potential. Access online http://www. besustainablemagazine.com/cms2/malaysias-biomass-potential/.

2. Rupani, P. F., Singh, R. P., Ibrahim, M. H. and Esa, N. (2010). Review of current palm oil mill effluent (POME) treatment methods: vermicomposting as a sustainable practice. World Applied Sciences Journal, 11(1): $70-81$. 
3. Iwuagwu, J. O. and Ugwuanyi, J. O. (2014). Treatment and valorization of palm oil mill effluent through production of food grade yeast biomass. Journal of Waste Management, 2014: 1 - 9.

4. Lorestani, A. (2006). Biological treatment of palm oil mill effluent (POME) using an up-flow anaerobic sludge fixed film (UASFF) bioreactor. Thesis Doctor of Philosophy, Universiti Teknologi Malaysia.

5. Khalid, K., Soon, E. M. L. and Chow, K. F. (1998). Microwave drying of palm oil mill effluent. Pertanika Journal of Science \& Technology, 6(2): $121-130$.

6. Salema, A. A. and Ani, F. N. (2010). Microwave pyrolysis of oil palm fibres. Jurnal Mekanikal, 30: 77 - 86.

7. Faris, N. A. F. A. (2014). Effect of power level on product yield for microwave pyrolysis of palm oil mill effluent (POME). Thesis Bachelor Chemical Engineering, Chemical Engineering Faculty, Universiti Teknologi MARA.

8. Ling, Y. L. (2007). Treatability of palm oil mill effluent (POME) using black liquor in an anaerobic treatment process. Thesis Doctoral of Philosophy, Universiti Sains Malaysia.

9. Borja, R., Banks, C. J., Martin, A. and Khalfaoui, B. (1995). Anaerobic digestion of palm oil mill effluent and condensation water waste: an overall kinetic model for methane production and substrate utilization. Bioprocess Engineering, 13(2): 87 - 95.

10. Neoh, C. H., Yahya, A., Adnan, R., Majid, Z. A. and Ibrahim, Z. (2013). Optimization of decolorization of palm oil mill effluent (POME) by growing cultures of Aspergillus fumigatus using response surface methodology. Environmental Science and Pollution Research, 20(5): 2912 - 2923.

11. Oswal, N., Sarma, P. M., Zinjarde, S. S. and Pant, A. (2002). Palm oil mill effluent treatment by a tropical marine yeast. Bioresource Technology, 85(1): $35-37$.

12. Agamuthu, P., Tan, E. L. and Shaiful, A. A. A. (1986). Effect of aeration and soil inoculum on the composition of palm oil mill effluent (POME). Agricultural Wastes, 15(2): 121 - 132.

13. Teng, T. T., Wong, Y. S., Ong, S. A., Norhashimah, M. and Rafatullah, M. (2013). Start-up operation of anaerobic degradation process for palm oil mill effluent in anaerobic bench scale reactor (ABSR). Procedia Environmental Sciences, 18: 442 - 450.

14. Abdurahman, N., Azhari, N. and Rosli, Y. (2013). The performance evaluation of anaerobic methods for palm oil mill effluent (POME) treatment: A review. INTECH Open Access Publisher.

15. Chin, K. K., Lee, S. W. and Mohammad, H. H. (1996). A study of palm oil mill effluent treatment using a pond system. Water Science and Technology, 34(11): 119 - 123.

16. Chooi, C. (1984). Ponding system for palm oil mill effluent treatment. Proceeding on Workshop of Palm Oil Mill Effluent Technology: pp. $53-63$.

17. Fakhru'l-Razi, A. and Noor, M. J. M. M. (1999). Treatment of palm oil mill effluent (POME) with the membrane anaerobic system (MAS). Water Science and Technology, 39(10-11): 159 - 163.

18. Mushtaq, F., Mat, R. and Ani, F. N. (2014). A review on microwave assisted pyrolysis of coal and biomass for fuel production. Renewable and Sustainable Energy Reviews, 39: 555 - 574.

19. Appleton, T. J., Colder, R. I., Kingman, S. W., Lowndes, I. S. and Read, A. G. (2005). Microwave technology for energy-efficient processing of waste. Applied Energy, 81(1): 85 - 113.

20. Calabrò, E. and Magazù, S. (2012). Comparison between conventional convective heating and microwave heating: an FTIR spectroscopy study of the effects of microwave oven cooking of bovine breast meat. Journal of Electromagnetic Analysis and Applications, 4(11): 433 - 449.

21. Ismail, K., Ishak, M. A. M., Ab Ghani, Z., Abdullah, M. F., Safian, M. T. U., Idris, S. S., Tahiruddin, S., Yunus, M. F. M. and Hakimi, N. I. N. M. (2013). Microwave-assisted pyrolysis of palm kernel shell: Optimization using response surface methodology (RSM). Renewable Energy, 55: 357 - 365.

22. Fernández, F., Arenillas, A., and Menéndez, J. Á. (2011). Microwave heating applied to pyrolysis, advances in induction and microwave heating of mineral and organic materials, Stanisław Grundas (Ed.). INTECH Open Access Publisher.

23. Wang, L., Lei, H., Ren, S., Bu, Q., Liang, J., Wei, Y., Liu, Y., Lee, G. S. J., Chen, S., Tang, J. and Zhang, Q. (2012). Aromatics and phenols from catalytic pyrolysis of Douglas fir pellets in microwave with ZSM-5 as a catalyst. Journal of Analytical and Applied Pyrolysis, 98: 194 - 200.

24. Khairuddin, M. N., Sulaiman, A., Syahlan, S., Zulkefli, F., Bula, J., Wan Abdul Rahman, W. M. N., Kassim, J., Md Isa, I. and Mat Tahir, M. R. (2013). Analysis and management of methane emissions from dumping pond: A cases study at Felda Jengka 8 palm oil mill. Proceeding KONAKA: pp. $35-41$. 
25. Januri, Z., Rahman, N. A., Idris, S. S., Matali, S., Manaf, S. F. A., Faris, N. A. F. A. and Rosland, N. (2014). Effect of activated carbon as microwave absorbance on the yields of microwave assisted pyrolysis of palm oil mill effluent. $3^{\text {rd }}$ IET International Conference on Clean Energy and Technology: pp. 1 - 9.

26. Januri, Z., Rahman, N. B. A., Idris, S. S., Matali, S., Manaf, A. and Fairuz, S. (2014). Yields performance of automotive paint sludge via microwave assisted pyrolysis. In Applied Mechanics and Materials. Trans Tech Publications: pp. $191-195$.

27. Zuo, W., Tian, Y. and Ren, N. (2011). The important role of microwave receptors in bio-fuel production by microwave-induced pyrolysis of sewage sludge. Waste Management, 31(6): $1321-1326$.

28. Salema, A. A., Yeow, Y. K., Ishaque, K., Ani, F. N., Afzal, M. T. and Hassan, A. (2013). Dielectric properties and microwave heating of oil palm biomass and biochar. Industrial Crops and Products, 50:366 - 374.

29. Meredith, R. (1998). Engineer's Handbook of Industrial Microwave Heating. London: The Institution of Electrical Engineers.

30. Lam, S. S., Russell, A. D., Lee, C. L. and Chase, H. A. (2012). Microwave-heated pyrolysis of waste automotive engine oil: Influence of operation parameters on the yield, composition, and fuel properties of pyrolysis oil. Fuel, 92(1): $327-339$.

31. Chemat, F. and Poux, M. (2001). Microwave assisted pyrolysis of urea supported on graphite under solventfree conditions. Tetrahedron Letters, 42(22): 3693 - 3695.

32. Xie, Q., Peng, P., Liu, S., Min, M., Cheng, Y., Wan, Y., Li, Y., Lin, X., Liu, Y., Chen, P. and Ruan, R. (2014). Fast microwave-assisted catalytic pyrolysis of sewage sludge for bio-oil production. Bioresource Technology, 172: $162-168$.

33. Dai, Q., Jiang, X., Wang, F., Chi, Y. and Yan, J. (2013). PCDD/Fs in wet sewage sludge pyrolysis using conventional and microwave heating. Journal of Analytical and Applied Pyrolysis, 104: 280 - 286.

34. Jiang, J. and Ma, X. (2011). Experimental research of microwave pyrolysis about paper mill sludge. Applied Thermal Engineering, 31(17): 3897 - 3903.

35. Menéndez, J. A., Domınguez, A., Inguanzo, M. and Pis, J. J. (2004). Microwave pyrolysis of sewage sludge: analysis of the gas fraction. Journal of Analytical and Applied Pyrolysis, 71(2): 657 - 667.1

36. Wang, X. H., Chen, H. P., Ding, X. J., Yang, H. P., Zhang, S. H. and Shen, Y. Q. (2009). Properties of gas and char from microwave pyrolysis of pine sawdust. BioResources, 4(3): 946 - 959.

37. Menendez, J. A., Inguanzo, M. and Pis, J. J. (2002). Microwave-induced pyrolysis of sewage sludge. Water Research, 36(13): $3261-3264$.

38. Thangalazhy-Gopakumar, S., Al-Nadheri, W. M. A., Jegarajan, D., Sahu, J. N., Mubarak, N. M. and Nizamuddin, S. (2015). Utilization of palm oil sludge through pyrolysis for bio-oil and bio-char production. Bioresource Technology, 178: 65 - 69.

39. Jing-Biao, Y. and Ning-Sheng, C. (2006). A TG-FTIR study on catalytic pyrolysis of coal. Journal of Fuel Chemistry and Technology, 34(6): $650-654$.

40. Domí, A., Menendez, J. A., Inguanzo, M., Bernad, P. L. and Pis, J. J. (2003). Gas chromatographic-mass spectrometric study of the oil fractions produced by microwave-assisted pyrolysis of different sewage sludges. Journal of Chromatography A, 1012(2): 193 - 206.

41. Xiong, S., Zhuo, J., Zhang, B. and Yao, Q. (2013). Effect of moisture content on the characterization of products from the pyrolysis of sewage sludge. Journal of Analytical and Applied Pyrolysis, 104: 632 -639.

42. Bolotov, V. A., Udalov, E. I., Parmon, V. N., Tanashev, Y. Y. and Chernouso, Y. D. (2012). Pyrolysis of heavy hydrocarbons under microwave heating of catalysts and adsorbents. Journal of Microwave Power and Electromagnetic Energy, 46(1): 39 - 46. 